\section{The Effect of Argumentation-Based Social Studies Teaching on Academic Achievement, Attitude and Critical Thinking Tendencies of Students*}

\author{
Nazile Yılmaz-Özcana , Sanem Tabakb, ${ }^{\text {,* }}$
}

$\begin{array}{ll}\text { Received: } & 24 \text { July } 2019 \\ \text { Revised: } & 11 \text { November } 2019 \\ \text { Accepted: } \quad 19 \text { December } 2019 \\ \text { ISSN: 1307-9298 } \\ \text { Copyright @ IEJEE } \\ \text { www.iejee.com }\end{array}$

DOI: 10.26822/iejee.2019257669

\begin{abstract}
Argumentation-based learning is important for individuals to gain a place in social life, to adapt themselves to social life, to solve the problems they encounter and to use critical and scientific approaches. At this point, it is considered that students should be supported to solve problems efficiently, to establish a cause-effect relationship and to research the scientific background of a problem by implementing argumentation-based learning in social studies course. Therefore, the aim of this research was determined as to reveal the effect of argumentation-based learning in the fourth-grade social studies course on the academic achievement, attitude and critical thinking tendencies of students. The study group of the research consisted of 51 fourth-grade students. This research included the embedded design from the mixed method designs. In the research, subject area achievement test, attitude towards the social studies course scale and UF/EMI Critical Thinking Tendency Scale and six activities that were developed in accordance with the argumentation-based learning approach were used as data collection tools. As a result of the research, it was determined that in social studies course with implementation of argumentation-based learning, the levels and qualities of the arguments that were developed by the students showed an increase throughout the research. Furthermore, it was concluded that with argumentation-based learning in social studies courses, positive developments were observed for academic achievement, attitude towards the social studies course and critical thinking tendencies of students.
\end{abstract}

Keywords: Argumentation-Based Learning, Social Studies, Critical Thinking Tendency

\section{Introduction}

Curricula are prepared for individuals to develop as people who pay attention to experiences, take an active part in social life and produce solutions to problems. Accordingly, social studies courses are considered an important field in keeping up with changes by ensuring students understand the world. For this reason, in order for students to understand the social studies course meaningfully, the necessity of establishing a cause-effect relationship, problem-solving and researching comes to prominence. Furthermore, possession of certain high-level thinking skills such as critical thinking, discussing, decision making, and scientific thinking are required in order for individuals to produce solutions to the problems they encounter in the present day.

Kabapınar (2014) emphasized that knowledge is a means rather than an end in the acquisition of social studies skills. For this reason, students are required to acquire knowledge about problem-solving, researching, establishing a cause-effect relationship and developing new projects in order for learning that occurs in social studies courses to be permanent and meaningful. Thus, it is suggested that students be given the opportunity to explain their opinions in an evidence-based way by using written materials in lessons. In accordance with this, it is considered that forming a basis for the social studies curricula allowing students to apply the information they learn in daily life and to transform it into skills such as problem-solving, critical thinking and decision-making will increase the effect of the social studies course on the life of the individuals (Önal \& Kaya, 2011: 27). Therefore, students would gain skills such as explaining and defending their opinions, asserting new claims and defending these claims. This situation would ensure students are more active, curious, and can research and in addition, can express themselves better. It is considered that the con- tribution of argumentation-based learning would be significant in the efficient provision of this process (Aydın \& Kaptan, 2014, s. 166).

\section{Argumentation-Based Learning}

Argumentation-based learning was developed by Toulmin (1958). Toulmin created an argument model based on his own perception. When the literature is examined, this model was discussed in several studies and it was especially used for the evaluation of arguments (Demirci, 2008; Deveci, 2009; Domaç, 2011; Erduran, Simon, \& Osborne, 2004; Gültepe, 2011; Hacıoğlu, 2011; Kelly \& Takao, 2002; Sadler \& Fowler, 2006; Simon, Erduran, \& Osborne, 2006; Yeşiloğlu, 2007). In this model, the structures that form an argument and how the relationship between them can be established is explained. Especially, claim, ground and warrant form the basis of this model. Toulmin revealed these in his research as a new discussion model as follows:

- Claim: The thesis that is asserted about the discussed subject.

- Ground: The information that is used to reach the asserted claims. In other words, the ground is evidence used for the defended claims.

- Warrant: The logical approach that provides the integrity of the claim and the ground.

- Backing: The element that completes the warrant at the point of accuracy.

- Rebuttal: The element that shows the asserted arguments to be invalid.

- Model Qualifiers: Situations in which the explained arguments would lose their validity. 
According to this model, the obtained data strengthens the claim in an argument. Reason establishes the relationship between the claim and the ground. That is, reason integrates the claim and the data. Rebuttal reveals that the argument is invalid, and the model qualifiers reveal that it is valid. The mode based on argumentation and developed by Toulmin in 1958 is shown in Figure 1.

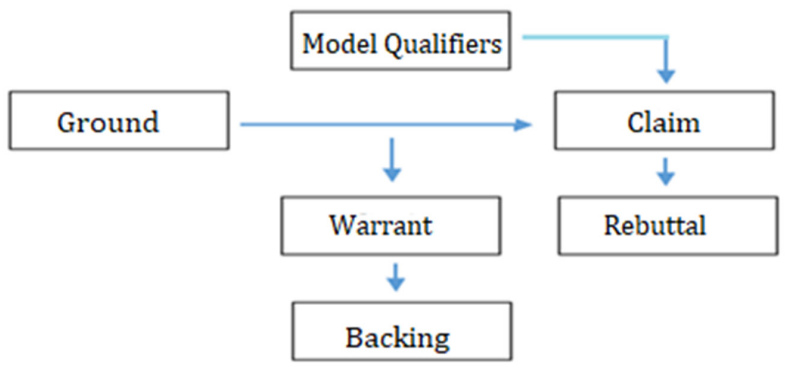

Figure 1. The Toulmin Model of Argumentation (1958)

The Toulmin model of argumentation offers alternatives in producing solutions to problems that individuals encounter in their daily lives, internalizing the argument and improving the critical thinking skill. Furthermore, in this model, the opinions of others can be agreed with and respected without the need for anyone or any source (Goodnight, 2006). For this reason, estimating, establishing a cause-effect relationship, convincing the opposing party and forming a ground are significantly important skills in this model which was developed by Toulmin (1958). With the help of this model, the argumentation and idea formulation skills of students develop in their own over time. In addition to this, most students learn which part and how they should intervene with a problem they encounter and acknowledge that criticism is, in fact, not a negative concept (Erduran, Simon, \& Osborne, 2004).

With argumentation-based learning ( $\mathrm{ABL})$, students learn by asking questions, creating claims, supporting their claims and questioning counter-arguments. Students are observed to actively participate in lessons with this learning approach (Günel, Kıngır, \& Geban, 2012: 318). With this learning approach, students gain skills such as obtaining data on the ideas they support, putting forward evidence, supporting their claims and writing the processes in relation to these (Kabataş-Memiş, 2014). Argumentation-based learning was designed in a way enables students to improve their verbal and written expression skills, to understand the nature of science and to scrutinize their ideas and skills in a critical approach (Sampson \& Clark, 2007). Students can clearly express what they feel about a subject through $A B L$. With the help of $A B L$, students learn the opinions of others while stating their opinions, have opinions, adopt the opinions that are suitable for them and discard the opinions that are not suitable for them (King, 1997). Argumentation is extremely important in terms of finding a place and keeping up with society, solving problems and using critical and scientific approaches (Nutt, 2008).

The initial questions that occur about ideas asserted during the process of argumentation are "Why do you think that?" "How do you know?" and "Why?". The argumentation process is regarded to start with these questions because individuals who seek answers to these questions begin to produce arguments and become involved in argumentation environments (Küçük \& Aycan, 2014). Therefore, students can apply decision-making methods by asking questions, revealing their evidence and comparing the claims that they created within a scientific framework (Yeşildağ-Hasançebi \& Günel, 2013). The active participation of students in the learning process increases and thus, efficient learning takes place with this learning approach. Argumentation-based learning has benefits in revealing the aspects of social studies courses such as being evidence-based and not based on rote-learning, putting for- ward ideas with different points of view and offering solutions to social problems. In the conducted studies, it was observed that the teaching methods in the evidence-based research model do not only improve academic achievement and motivation towards efficient learning in science but also in fields such as social studies, reading-writing, mathematics, and foreign language (ilter, 2013).

\section{Importance of Critical Thinking Skill in Social Studies Teaching}

Hesapçıoğlu (1991) defines thinking as "a cognitive synthesizing and an intellectual process that reaches knowledge" and the concept of cognition as "awareness, reasoning, intuition". Despite its importance and necessity, students cannot comprehend that thinking is one of the most important objectives of education. There is a number of students who believe that teachers should explain the answers instead of believing it is their duty to seek answers to the questions that lead to thinking. These students believe that listening to their teacher instead of thinking and producing new ideas would get them higher marks. However, the main objectives of current education approaches across the world are providing individuals with the opportunity to gain skills such as problem-solving and critical thinking (Hesapçıŏlu, 1991).

Critical thinking is a way of thinking that does not seek negative features, and is not a prejudiced approach, uncontrolled way of thinking, nitpicking, simple and meaningless or presents contradictory behavior to every opinion (Güzel, 2005). Critical thinking which is not a negative evaluation method in itself aims to "explain and evaluate a subject by revealing both the positive and negative aspects". A systematic path should be followed using certain steps while performing this.

Gürkaynak, Üstel and Gülgöz (2008) define the necessity for critical thinking under two main titles:

1. Individualization: Individuals need critical thinking skills in order to make their own decisions, to solve problems they encounter and to be independent individuals without the need to be directed by other people.

2. Citizenship: Modern societies consider critical thinking as an important quality for individuals who are aware of their responsibilities, predicate on reason and science, produce new ideas and support them, assess other ideas, establish empathy/sympathy and respect different ideas.

When all of the features of critical thinking that are stated above are considered, the necessity of possessing this skill comes to prominence. Accordingly, when the curriculum of the social studies course in Turkey, developed on the constructivist approach since 2005, is examined it can be observed that critical thinking skills are included within general skills and the aim is to acquire this skill with discipline. From this point of view, it can be stated that the social studies course is an appropriate subject field for the acquisition of critical thinking skills.

\section{Aim and Importance of the Research}

When the studies conducted in the education field are ex amined, it can be observed that new and different methods and techniques have begun to be used in many fields. Among these studies, studies conducted about the argumentation-based learning which is effective in the development of decision-making, argumentation and communication skills of students attract attention. Today, the argumentation-based learning method is preferred in the fields of social studies and science; however, studies and projects about this learning approach mainly focus on the field of science (Antilia, 2012; Butt, 2010; Chin \& Osborne, 2010; Crowell \& Kuhn, 2012; Dus- 
chl \& Osborne, 2002; Erduran, Simon, \& Osborne, 2004; Hudson, 2010; Sadler \& Fowler, 2006; Simon, Erduran, \& Osborne, 2006; Thielemier, 2013; Zohar \& Nemet, 2002). Studies about argumentation-based learning in social studies have begun to gain momentum in recent years (Akbaş \& Çetin, 2018; Demir \& Oğuz-Haçat, 2017; Larson, Britt, \& Kurby, 2009; Mirza \& Perret-Clermont, 2009; Nussbaum, 2002; 2008; Swartz, 2008; Torun \& Şahin, 2016; Wissinger, 2012; Yazıcıoğlu, 2017). The tendencies of these studies are mainly about the argumentation process, the students' level of producing argumentation, decision-making, and problem-solving skills.

Argumentation-based learning is included in the teaching methods in the curriculum which has been applied since 2005 in Turkey. However, since there aren't many studies about social studies, this research is expected to be an example for teachers. For this reason, it is considered to contribute to the literature since the gains in the "People, Places and Environments" unit which is included in the curriculum of the social studies course are researched for the first time.

Considering the features of argumentation-based learning and critical thinking skills, it is considered that activities included in the argumentation-based learning process in the social studies course would affect the critical thinking skills of students and the aim is to reveal the changes in the achievement and attitude of students by developing sample activities which are aimed at the acquisition of this skill.

This research aimed to investigate the development of argumentation levels of students during social studies course designed with argumentation-based learning and to investigate the effect of argumentation-based learning on the academic success, attitude toward social studies course and critical thinking tendencies of students.

In accordance with this aim, the answers to the following questions were sought:

1. How have the argument levels formed by experimental group improved after the social studies course in which argumentation-based teaching is performed?

2. Is there a significant difference between the academic achievement of students in the experimental group who received argumentation-based social studies education and the students in the control group who received the standard curriculum social studies course?

3. Is there a significant difference between the attitude of students towards the social studies course in the experimental group who received argumentation-based social studies education and the students in control group who received the standard curriculum social studies course?

4. Is there a significant difference between the critical thinking tendencies of students in the experimental group who received argumentation-based social studies education and the students in the control group who received the standard curriculum of social studies course?

\section{Method}

\section{Research Model}

The research investigated the effect of argumentation-based learning on the academic success, attitude toward social studies course and critical thinking tendencies of students with the quantitative research method of pretest-posttest in a controlled experimental model. The experimental phase of the research consists of three stages: planning, introduction and conducting of the application. Accordingly, in the planning stage of the experimental application, the necessary permissions were taken from the school where the research will be conducted first. Then, the classes in the school where the application will be done were determined and preliminary application of the data collection tools of the research was made. Before the study started on the experimental group identified in the study, information about argumentation-based learning was given. During the experimental process, activities developed by researchers were applied each week and evaluated by to the "Argumentation Assessment Rubric". Experimental application stage in the study lasted six weeks in total. After the experimental process was completed, the last applications of the data collection tools of the research were made. With the aim of revealing the experimental process included in the research and investigating the argumentation levels developed by students in social science course supported by argumentation-based learning, the qualitative research method of basic qualitative research methods were included. The basic qualitative research model discusses how people perceive and interpret their lives and experiences and can be observed in all of the disciplines. In basic qualitative research, the data is obtained through interviews, observations or document review. The selected data collection tool is shaped in accordance with the theoretical framework of the research (Merriam, 2013). In this research, which is based on argumentation-based learning, the activities performed by the students were examined in detail through observations of the researcher and document review in order to determine the argumentation levels of students in the social studies course. Accordingly, since the understanding and the arguments of students about the concepts included in the "People, Places and Environments " unit in the social studies course were examined, the basic qualitative research design was preferred in this research.

During the experimental process in the research, the development of argumentation levels among students was investigated. In line with this, to support elements in the experimental model included in the research and to test the intervention during the experimental process, quantitative and qualitative data were collected simultaneously. As a result, this research included the embedded design from the mixed method designs. Creswell and Plano Clark (2011) defined the embedded design as studies with simultaneous collection of quantitative and qualitative data, where each data type is submerged within another data type.

\section{Study Group}

The study group in this research consists of two groups determined with the random method among fourth grade classes of an elementary school selected with convenient sampling in the academic year 2017-2018 in the Altınordu district of Ordu province by considering reasons such as the eager attitudes of school administration, teachers and students in assisting the researcher and decent technical infrastructure and physical conditions of the school. One of these groups were included as the experimental group and the other was included as the control group in the research. The distributions in the experimental and control groups of 51 students who participated in the quantitative dimension of the research are given in Table 1.

Table 1. Distribution of Students within the Study Group in the Experimental and Control Groups

\begin{tabular}{lrr}
\hline Groups & $N$ & $\%$ \\
\hline Experimental & 27 & 53 \\
\hline Control & 24 & 47 \\
\hline Total & 51 & 100 \\
\hline
\end{tabular}

When Table 1 which illustrates the distribution of students within the study group in the experimental and control 
groups is examined, it can be observed that $53 \%$ of the students were in the experimental group and $47 \%$ of them were in the control group.

Attention was taken to select groups which are close to each other in terms of variables such as academic achievement, attitude towards the social studies course and critical thinking tendencies. Accordingly, the subject area achievement test, attitude towards social studies course scale and critical thinking tendencies scale were applied to the experimental and control groups. The independent groups $t$-test was conducted in order to determine the conditions of students before the application and the results of the analysis are presented in Table 2

When Table 2 is examined, it can be observed that there was no statistically significant difference between the pre-test scores of academic achievement, attitude towards the social studies course and critical thinking tendencies of students in the experimental and control groups $\left[t_{a c h(51)}=.285 ; t_{\text {att(51) }}=-1.339 ; t_{c t(51)}=\right.$ $-2.382 ; p>.05]$. This finding indicates that the pre-knowledge of students in the experimental and the control groups before the application is equal and there is no difference between the two groups in terms of attitude towards the social studies course and critical thinking tendencies.

The study group for the qualitative dimension of the research consists of students in the experimental group $(N=27)$ in which argumentation-based learning was applied.

\section{Data Collection Tools}

Achievement Test, Attitude towards the Social Studies Course Scale, Critical Thinking Tendency Scale, and worksheets that were developed by the researchers about argumentation-based learning were used as data collection tools.

\section{Achievement test}

Ninety multiple-choice questions which evaluate acquisitions in the "People, Places and Environments" unit were prepared by the researchers. Between 8 to 10 sub-acquisitions related to the acquisitions in the curriculum of the social studies course were prepared before the questions. Attention was paid to prepare the questions within the framework of these sub-acquisitions. In order to provide content validity of these questions, the opinions of four social sciences educators, two social studies teachers and one Turkish teacher were sought to checking the grammar. Necessary corrections were performed within the framework of these opinions. Specialists were asked to choose the questions that were appropriate to the acquisition. After all the specialist opinions were evaluated, 30 questions were suitable for the acquisitions. The validity and reliability studies of these questions were conducted with a total of 154 students in six groups from fifth grade which received education about these subjects in a secondary school in the Altınordu district of Ordu province. The answers of students were evaluated with Item and Test Analytics Program (ITEMAN). "Skewness" and "Kurtosis" values were examined in order to understand whether or not the distinctiveness index shows normal distribution and since this value was near to 0 (.96), it was interpreted that it shows normal distribution. As a result of the conducted analyses, the most difficult questions were determined as 6,7 and 15 and questions with low item distinctiveness were determined as 6, 29, 15, 1 and 30. The $1^{\text {st }}$, $6^{\text {th }}, 15^{\text {th }}, 29^{\text {th }}$, and $30^{\text {th }}$ questions were removed in accordance with the obtained results and the number of questions in the achievement test was reduced to 25 . The Cronbach Alpha internal consistency coefficient for the test was determined as .87. The test which consisted of 25 questions was applied to both the experimental and control group as pre-test and posttest achievement test.

\section{Attitude towards the social studies course scale}

In the research, a Likert type attitude scale included in the curriculum of the social studies course (MNE, 2017) was used in order to measure the attitudes of students towards the social studies course.

\section{UF/EMI critical thinking tendency scale}

The Critical Thinking Tendency Scale is a measurement tool which was developed in the University of Florida as a tool that accurately measures the critical thinking tendency and at the same time includes fewer factors than the existing measurement tools. The scale was adapted to Turkish by Ertaş-Kılıç \& Şen (2014). After the translation of Critical Thinking Tendency Scale to Turkish, the five-point Likert scale with 26 items was applied to 342 students who were studying in the ninth and tenth grade in order to determine the reliability and validity of the scale in Turkey. The examination of the scale was conducted with Confirmatory Factor Analysis (CFA) and one item was removed from the scale. According to the results, this scale is consistent, original and coherent with the data. The Cronbach Alpha values of the scale were determined as .88 for participation sub-dimension, .91 for the internal consistency coefficient of the scale, .73 for the innovativeness sub-dimension and .70 for the cognitive maturity sub-dimension (Ertaş-Kılıç \& Şen, 2014). This five-point Likert scale consists of 25 items.

\section{Worksheets}

Six worksheets were prepared by the researcher in accordance with the acquisitions included in the "People, Places and Environments" unit in order to reveal the argumentation development levels of students who are in the fourth grade. Before the development of the worksheets, studies about how worksheets can be used in the social studies course are prepared (Torun \& Şahin, 2016; Kardaş, 2013) were examined by the researcher and research was completed about why worksheets are important in teaching. The researcher also reviewed worksheets that were pre-prepared and used in the lessons. A total of 6 worksheets were developed in the research. The first four of the worksheets, "Students at Scout Camp, Drawing Sketch, Our Environment is Changing and How is the Weather around There", were fictionalized by the researcher. The other two worksheets, "Places in the Legends, Ballads, and Poets" and "I Am Learning Natural Disasters, Living Safe" were prepared by benefiting from the Educational Informatics Network (EIN).

In the initial sections of the worksheets, reading texts ensuring students think according to the argumentation-based learning approach were prepared in accordance with the subjects and acquisitions. In the second part, assessment questions were

Table 2. Comparison of the Pre-Test Scores of Students in the Experimental and Control Groups

\begin{tabular}{|c|c|c|c|c|c|c|c|}
\hline & Groups & $N$ & M & $s d$ & $d f$ & $t$ & $p$ \\
\hline \multirow{2}{*}{ Academic Achievement } & Experimental Group & 27 & 67.740 & 17.366 & 49 & -.285 & .777 \\
\hline & Control Group & 24 & 66.166 & 18.234 & & & \\
\hline \multirow{2}{*}{ Attitude towards the Social Studies Course } & Experimental Group & 27 & 4.267 & .592 & 46 & -1.339 & .187 \\
\hline & Control Group & 24 & 4.006 & .750 & & & \\
\hline \multirow{2}{*}{ Critical Thinking Tendencies } & Experimental Group & 27 & 3.510 & .485 & 46 & -2.382 & .051 \\
\hline & Control Group & 24 & 3.461 & .499 & & & \\
\hline
\end{tabular}


included which were prepared in accordance with the Toulmin Model of Argumentation (1958) aimed at understanding the reading texts.

A pilot scheme was conducted by the researcher with fourthgrade students in another group which were studying in the same school but were not included in the research. In the pre-application, it was observed that students experienced difficulty in producing qualified claims. For this reason, students were allowed to complete the activities by presenting alternative answers in the first three worksheets. Thus, an attempt was made to prevent incomprehensibility that may emerge. In the subsequent process, students were asked to create a ground to their claims and to base their claims on scientific grounds. They were asked to develop backing elements in examples that would strengthen their claims and rebuttals for the opposing ideas that they didn't agree with. In accordance with the pilot scheme results, the worksheets were reviewed by four lecturers who were employed in the department of educational sciences and necessary adjustments were made by paying attention to the suggestions.

\section{Analysis of the Data}

The normal distribution of the data is stated as a precondition for conducting statistical analyses in the studies. Accordingly, if the coefficient of skewness is "0", it shows symmetrical distribution according to the average and if the coefficient of skewness is between +1 and -1 it can be interpreted that the scores do not show a significant deviation from normal distribution (Büyüköztürk, 2007). In the analyses, the coefficient of skewness of the scores in achievement, attitude and critical thinking tendencies was calculated as .783. It is possible to state that this data is between -1 and +1 and the scores show normal distribution.

Within the scope of the research, for the analysis of the quantitative data, the statistical analyses of the independent sample $t$-test were conducted in the SPSS 21 program in order to compare the scores for academic achievement, attitude towards the social studies course and critical thinking tendencies of students in the experimental and control groups before and after the application. The significance levels of the analyses of the statistical data in the research were accepted as .05.

For the analysis of qualitative data, first, the activities students performed were examined while analyzing the arguments that were created by the students and they were analyzed according to the "Argumentation Assessment Rubric" which was developed by Torun and Şahin (2016). This rubric developed by Torun and Şahin (2016) is a modified version of the "Argumentation Assessment Scale" prepared by Toulmin (1958) and adapted to Turkish by Erduran, Simon and Osbourne (2004). Activities that were applied on the basis of this rubric (Table 3 ) were evaluated in terms of including the elements included in the Toulmin model of argumentation.

As can be understood from Table 3, the arguments are level one if they only have one claim, level two if they have reason and claim, level three if they have weak rebuttal, reason and claim, level four if they have claim and clearly stated rebuttal, level four if they have reason and clearly defined rebuttal and level five if they are comprehensive, have more than one rebuttal and take longer time. The arguments were coded according to their levels. The arguments in level one were coded as 1, in level two were coded as 2, in level 3 were coded as 3 , in level four as 4 and in level five as 5 .

In qualitative studies, one of the methods preferred to ensure the reliability of data is peer debriefing. Accordingly, the obtained data from the argumentation activities that students performed were examined in accordance with the argumentation assessment rubric with 3 teachers completing master's degrees in the field of primary education and one lecturer who was a specialist in social studies education. The level of argumentations were created by the students was determined. As a result of this evaluation conducted with specialists, a consensus was reached about the argumentation levels of students. Through the specialist examination and provision of consensus, it is considered that the reliability and validity of this research were ensured by plausibility and validity which are taken as basis for the provision of validity and reliability in qualitative research, as stated by Yıldırım and Şimşek (2016).

\section{Findings}

The first sub-problem of the research was stated as "How have the argument levels formed by experimental group improved after the social studies course in which argumentation-based teaching is performed?". In accordance with this sub-problem, the levels of arguments that were produced by the students and how many students were in each level were determined (Figure 2).

According to Figure 2, it can be observed that the levels of argumentations produced by the students increased within the application period. Six argumentation activities were developed in accordance with the Toulmin Model of Argu-

Table 3. Argumentation Assessment Rubric (Torun \& Şahin, 2016)

\begin{tabular}{|c|c|c|}
\hline ArgumentationLevel & Score & Argumentation Content (Criterion) \\
\hline \multirow{3}{*}{ Level 1} & 1 & No clear claim (Indirect claim) \\
\hline & 2 & A simple claim \\
\hline & 3 & A simple claim and counter-claim \\
\hline \multirow{3}{*}{ Level 2} & 1 & Claim + ground \\
\hline & 2 & Claim + ground + reason \\
\hline & 3 & Claim + ground + reason + backing \\
\hline \multirow{3}{*}{ Level 3} & 1 & Claim + ground \\
\hline & 2 & Claim + ground + reason + rebuttal (Weak, unclear) \\
\hline & 3 & Claim + ground + reason + backing + rebuttal (Weak, unclear) \\
\hline \multirow{3}{*}{ Level 4} & 1 & Claim + ground + rebuttal (Clear, explicit, strong, one) \\
\hline & 2 & Claim + ground + reason + rebuttal (Clear, explicit, strong, one) \\
\hline & 3 & Claim + ground + reason + backing + rebuttal (Clear, explicit, strong, one) \\
\hline \multirow{3}{*}{ Level 5} & 1 & Claim + ground + rebuttal (More than one, clear) \\
\hline & 2 & Claim + ground + reason + rebuttal (More than one, clear) \\
\hline & 3 & Claim + ground + reason + backing + rebuttal (More than one, clear) \\
\hline
\end{tabular}


mentation and named "1st week, $2^{\text {nd }}$ week" were analyzed according to the "Argumentation Assessment Rubric" which was developed by Torun and Şahin (2016) and the obtained results from the analyses are presented in Table 4.

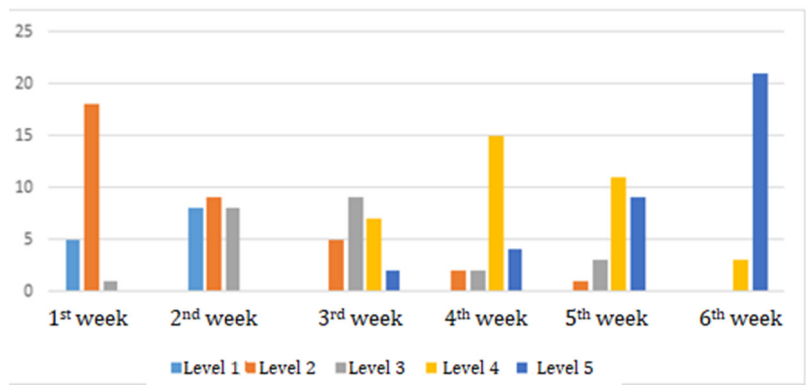

Figure 2. Argumentation Production Levels of Students according to Week

Table 4. Argumentation Levels and Number of Students

\begin{tabular}{lcrrrrr}
\hline Application & Level 1 & Level 2 & Level 3 & Level 4 & \multicolumn{2}{c}{ Level 5 } \\
& $N$ & $N$ & $N$ & $N$ & $N$ \\
\hline $1^{\text {st }}$ week & 5 & 18 & 1 & - & - \\
\hline $2^{\text {nd }}$ week & 8 & 9 & 8 & - & - \\
\hline $3^{\text {rd }}$ week & - & 5 & 9 & 7 & 2 \\
\hline $4^{\text {th }}$ week & - & & 2 & 15 & 4 \\
\hline $5^{\text {th }}$ week & & 1 & 3 & 11 & 9 \\
\hline $6^{\text {th }}$ week & - & - & - & 3 & 21 \\
\hline
\end{tabular}

When the findings about the first sub-problem of the research are examined, the arguments of students improved through argumentation-based learning. While only claims or reasons were dominant in the initial weeks, it was observed that rebuttals and backings were added to these in the final weeks. The activities that were applied week by week about this problem were examined and the findings are summarized below:

$1^{\text {st }}$ Week: The first activity prepared as a result of argumentation-based teaching was applied to the students. As demonstrated in Figure 2 and Table 4, students experienced difficulties in producing arguments with this unfamiliar method in the first week. Five students produced arguments on level 1, 18 students produced arguments on level 2 and 1 student produced arguments on level 3 (Figure 2).

$2^{\text {nd }}$ Week: In this week in which students understood this learning method better, an improvement was observed in the levels of arguments produced. It can be observed that 8 students produced arguments on level 1, 9 students produced arguments on level 2 and 8 students produced arguments on level 3.

$3^{\text {rd }}$ Week: It can be observed that students no longer produced arguments on level 1. It was determined that they put forward more qualified arguments. Five students produced arguments on level 1, 9 students produced arguments on level 2, 7 students produced arguments on level 3 and 2 students produced arguments on level 5.

$4^{\text {th }}$ Week: The argument-producing skills of students increased as a result of the argumentation-based learning. Two students produced arguments on level 2, 2 students produced arguments on level 3, 15 students produced arguments on level 4 and 4 students produced arguments on level 5.

$5^{\text {th }}$ Week: Students no longer experience difficulty in produc ing arguments with argumentation-based learning. One student produced arguments on level 2, 3 students produced arguments on level 3,11 students produced arguments on level 4 and 9 students produced arguments on level 5. $6^{\text {th }}$ Week: In the activities that were performed in this week, students adopted argumentation-based learning. Three students produced arguments on level 4 and 21 students produced arguments on level 5.

According to this situation, it can be concluded that argumentation-based learning and group discussions performed in the classroom environment positively affected the argument-producing skills of students.

The second sub-problem of the research was stated as "Is there a significant difference between the academic achievement of students in the experimental group who received argumentation-based social studies education and the students in control group who received the standard curriculum of social studies course?". Within the scope of this sub-problem, the independent sample $t$-test was conducted in order to determine whether or not there is a significant difference between the academic achievement of students in the experimental and control groups after the application.

Table 5. Comparison of the Academic Achievement of Students in the Experimental and Control Groups after the Application

\begin{tabular}{lrrrrrr}
\hline Groups & $N$ & $M$ & $s d$ & $d f$ & $t$ & $p$ \\
\hline Experimental Group & 27 & 88.444 & 12.762 & 49 & 2.685 & $.010^{*}$ \\
\hline Control Group & 24 & 77.666 & 15.555 & & & \\
\hline${ }^{*} p<.05$ & & & & & &
\end{tabular}

As can be seen in Table 5, a statistically significant difference was determined in favor of the experimental group between the posttest scores of students in the experimental and control groups $\left[t_{(51)}=2.685, p<.05\right]$. This finding can be interpreted as the social studies course in which argumentation-based learning is included being effective on the achievements of students.

The third sub-problem of the research was determined as "Is there a significant difference between the attitude of students towards the social studies course in the experimental group who received argumentation-based social studies education and the students in control group who received the standard curriculum of social studies course?". Within the scope of this sub-problem, the independent sample $t$-test was conducted in order to determine whether or not there is a significant difference between the attitudes of students in the experimental and control groups after the application and the results are presented in Table 6.

Table 6. Comparison of the Attitudes of Students in the Experimental and Control Groups after the Application

\begin{tabular}{lrrrrrr}
\hline Groups & $N$ & $M$ & $s d$ & $d f$ & $t$ & $p$ \\
\hline Experimental Group & 27 & 4.666 & .367 & 46 & -3.309 & $.002^{*}$ \\
\hline Control Group & 24 & 4.131 & .702 & & & \\
\hline
\end{tabular}

${ }^{*} p<.05$

As seen in Table 6, a statistically significant difference was determined in favor of the experimental group between the attitudes of students in the experimental and control groups $\left[t_{(51)}=\right.$ $-3.309, p<.05]$. This finding can be interpreted as the social studies course including argumentation-based learning positively affecting the attitudes of students towards the social studies course.

Within the scope of the fourth sub-problem in the research, an answer was sought to the question "Is there a significant difference between the critical thinking tendencies of students in the experimental group who received argumentation-based social studies education and the students in control group who received the standard curriculum of social studies course?". Within the scope of this sub-problem, the independent sam- 
ple t-test was conducted in order to determine whether or not there is a significant difference between the critical thinking tendencies of students in the experimental and control groups after the application and the analysis results are presented in Table 7.

Table 7. Comparison of the Critical Thinking Tendencies of Students in the Experimental and Control Groups after the Application

\begin{tabular}{lrrrrrr}
\hline Groups & $N$ & $M$ & $s d$ & $d f$ & $t$ & $p$ \\
\hline Experimental Group & 27 & 3.876 & .236 & 46 & -3.468 & $.001^{*}$ \\
\hline Control Group & 24 & 3.485 & .504 & & & \\
\hline
\end{tabular}

${ }^{*} p<.05$

As seen in Table 7, a statistically significant difference was determined in favor of the experimental group between the critical thinking tendencies of students in the experimental and control groups $\left[t_{(51)}=-3.468, p<.05\right]$. This finding can be interpreted as the social studies course including argumentation-based learning positively affecting the critical thinking tendencies of students.

\section{Discussion, Conclusion and Suggestions}

The argumentation levels of fourth-grade students, their academic achievement levels, critical thinking tendencies and attitudes towards the social studies course were examined at the end of the argumentation-based social studies teaching.

Within the first sub-problem of the research, an attempt was made to determine the levels of arguments that students produced in the social studies course including argumentation-based learning. Worksheets developed by the researchers in accordance with the argumentation-based learning were used throughout the application for the students in the experimental group. Within the framework of these worksheets, findings were obtained about this sub-problem by examining the arguments that were produced by the students. When the obtained findings about this problem are examined, it was observed that the level of arguments produced by the students started to increase after the second week. At the end of the sixth week, it was determined that the level of arguments produced by the students showed a positive increase from the first week to the last week and the level of arguments increased.

Studies were conducted by Kolsto (2006), Mirza and Perret-Clermont (2009), and Crowell and Kuhn (2012) which indicate that argumentation is both a method and a skill. As a result of the applications performed in this research, it was observed that the argumentation skill levels of fourthgrade students increased during the social studies course in which argumentation-based learning was taken as a basis. Therefore, this situation supports the findings of studies which indicate that argumentation is not only a method but also a skill.

At the start of the application with argumentation-based learning, the students contributed to the study only with simple claims they proposed. However, these students started to produce certain arguments with backings or reasons in later phases. The arguments of the students were observed to be more qualified towards the end of the application. When the literature is examined, students produce more qualified arguments as their argument levels develop in classroom environments where argumentation-based learning takes place (Crowell \& Kuhn, 2012; Çetin, Kutluca, \& Kaya, 2013; Kuhn \& Moore, 2015; Kuhn \& Udell, 2003; Sampson \& Clark 2007; Wissinger, 2012). In addition, it was observed that student discussions had a positive effect on acquiring discussion and critical thinking tendencies to the students through the activities conducted as part of the study.

When the findings regarding the second sub-problem in the study are evaluated, after argumentation-based learning applications, the academic achievement levels of the students increased with activities that enabled them to produce argumentation. There are studies in the literature about the effects of argumentation-based learning on the academic achievement levels of students within the framework of this sub-problem (Altun, 2010; Ceylan, 2010; Demirci, 2008; Deveci, 2009; Kıngır, 2011). Therefore, the obtained findings are in parallel with the literature.

When the findings regarding the third sub-problem in the study are evaluated, it was seen that after argumentation-based learning applications, the attitudes of the students in the experimental group towards the social studies course became more positive compared to the students in the control group. There are studies in the literature about the effects of argumentation-based learning on the attitudes of students towards the course within the framework of this sub-problem (Özkara, 2011; Tekeli, 2009). However, the studies conducted in this context are generally about the subject of science. In this study, the social studies course, including argumentation-based learning, was evaluated and at the end of the research it was observed that there was a change in the attitudes of the students towards the social studies course. It can be stated that this is due to the activities developed within the scope of the study, the group studies conducted during those activities, and argumentation-based learning, which is included in the social studies course in a different manner.

When the findings regarding the fourth sub-problem in the study are evaluated, after argumentation-based learning applications, there was a significant difference in favor of the experimental group for the critical thinking tendencies of the experimental group and the control group. This might be due to the fact that the critical thinking tendencies of the students are developed more in a learning environment where argumentation-based learning takes place. This is due to the development of the students in the argumentation-based learning activities and the in-class discussions.

In this study, it was observed that the students' level of academic achievement, attitude towards the subject of social studies, and critical thinking tendencies improved during the social studies course where applications based on argumentation-based learning were included. Accordingly, the necessity to include an argumentation-based learning approach in the social studies course comes to prominence. It is thought that, especially by establishing discussion platforms in the social studies course, teaching can be performed more efficiently by enabling students to contemplate scientific data and use these data with their reasons through the conduction of these discussions as arguments. Accordingly, it is important to include argumentation-based learning in areas such as the social studies course where student discussions can be established.

One of the processes performed before the research was examination of the social studies curriculum and the acquisition, contents, and activities in the curriculum that are suitable for argumentation-based learning. While the curriculum is suitable in terms of content and acquisition, it is notable that the number of activities that would help the realization of argumentation-based learning is low. For this reason, activities involving argumentation-based learning should be included more in social studies curricula.

When the literature was examined, it was observed in this and many other similar studies (Patronis, Potari, \& Spiliotopoulou, 1999; Nussbaum, 2002; Simon \& Richardson, 2009) that the students became more interested, participated actively, and were able to produce qualified arguments 
with the inclusion of real-life problems in the activities used during argumentation-based learning. Accordingly, the subjects included in the social studies curriculum should be chosen from daily life, should be contemporary, and presented in a way that attracts the attention of students. Therefore, students will be supported to produce arguments and obtain problem-solving skills in daily life.

When the literature is examined, there is a limited number of studies about argumentation-based social studies teaching. From this point of view and in the obtained results, studies that examine the effects of the social studies course based on the argumentation-based learning, the achievement levels of students and attitudes towards the social studies course should be performed.

The examined studies show that argumentation-based learning improves the argumentation levels of students and enables them to produce more qualified arguments. However, there are almost no studies in Turkey about argumentation-based learning in social studies teaching and its effect on academic achievement, attitude and critical thinking tendencies. At this point, it can be suggested that argumentation-based learning should be studied in other fields, especially in social studies teaching, rather than studies which primarily focus on the field of science education.

The effects of this learning method, which enables the use of different thinking skills at the same time, on academic achievement, attitude and critical thinking tendencies skills were revealed in this study. It is considered that this method will be effective in obtaining various skills such as reflective thinking, creative thinking, decision making and problem-solving in the social studies course. For this reason, studies that examine the effects of using argumentation-based learning in social studies teaching on reflective thinking, creative thinking, decision making, and problem-solving skills should be conducted.

\section{References}

Akbaș, M. \& Çetin, P. S. (2017). The investigation of gifted students' argumentation level and informal reasoning related to socio-scientific issues. Necatibey Faculty of Education Electronic Journal of Science and Mathematics Education, 12(1), 339-360.

Altun, E. (2010). Işık ünitesinin ilköğretim öğrencilerine bilimsel tartısma (argümantasyon) odaklı yöntem ile öğretimi. Unpublished Master's Thesis, Gazi University, Ankara.

Antilia, A. (2012). The effect of an argumentation diagram on the self-evaluation of a creative solution. Unpublished Doctoral Dissertation, Pennsylvania State University, Pennsylvania.

Aydın, Ö. \& Kaptan, F. (2014). Fen-teknoloji öğretmen adaylarının eğitiminde argümantasyonun biliş üstü ve mantıksal düşünme becerilerine etkisi ve argümantasyona ilişkin görüşler [Effect of argumentation on metacognition and logical thinking abilities in science - technology teacher candidate education and opinions about argumentation], Journal of Educational Sciences Research, 2(4), 164-188.

Butt, N. (2010). Argument construction, argument evaluation and decision-making: a content analysis of argumentation and debate textbooks. Unpublished Doctoral Dissertation, Wayne State University, Michigan.

Büyüküöztürk, Ş. (2007). Sosyal bilimler için veri analizi el kitabı. Ankara: PegemA Yayıncılık.

Ceylan, Ç. (2010). Fen laboratuvar etkinliklerinde argümantasyon tabanlı bilim öğrenme (ATBÖ yaklaşımının kullanımı). Unpublished Master's Thesis, Gazi University, Ankara.
Chin, C., \& Osborne, J. (2010). Students questions and discursive interaction: their impact on argumentation during collaborative group discussions in science. Journal of Research in Science Teaching, 47(7), 883-908.

Creswell, J. W., \& Plano Clark, V. L. (2011). Designing and conducting mixed methods research (2nd Ed.). London: Sage Publications Ltd.

Crowell, A., \& Kuhn, D. (2012). Developing dialogic argumentation skills: a three-year intervention study. Journal of Cognition and Development, 15(2), 363-381.

Çetin, P. S., Kutluca, A. Y., \& Kaya, E. (2013). Öğrencilerin argümantasyon kalitelerinin incelenmesi. Fen Eğitimi ve Araştırmaları Derneği Fen Bilimleri Öğretimi Dergisi, 2(1), 56-66.

Demir, F. B. \& Oğuz -Haçat, S. (2017) Sosyal bilgiler öğretmen adaylarının argümantasyona dayalı eğitim sürecine göre argüman düzeylerinin belirlenmesi [An exploration the status of social studies teacher candidates' oral argumentation regarding the right and responsibility issue]. Turkish Scientific Researches Journal, 3(1), 68-82.

Demirci, N. (2008). Toulmin'in argümantasyon modeli temelli eğitimin kimya ögretmen adaylarının temel kimya konularını anlamaları ve tartısma seviyeleri üzerine etkisi. Unpublished Master's Thesis, Gazi University, Ankara.

Deveci, A. (2009). Illköğretim yedinci sınıf öğrencilerinin maddenin yapısı konusunda sosyobilimsel argümantasyon, bilgi seviyeleri ve bilişsel düşünme becerilerini geliştirmek. Unpublished Master's Thesis, Marmara University, İstanbul.

Domaç, G. (2011). Biyoloji eğitiminde toplumbilimsel konuların ögrrenilmesinde argümantasyon tabanlı öğrenme sürecinin etkisi. Unpublished Master's Thesis, Gazi University, Ankara.

Duschl, R. \& Osborne, J. (2002). Supporting and promoting argumentation discourse in science education. Studies in Science Education, 38, 39-72.

Erduran, S., Simon, S., \& Osborne, J. (2004). Tapping into argumentation: developments in the application of Toulmin's argument pattern for studying science discourse. Science Education, 88(6), 915-933.

Ertaş-Kılıç, H., \& Şen, A.I. (2014). Turkish adaptation study of UF/ EMI critical thinking disposition instrument. Education and Science, 39(176), 1-12.

Gelen, G. (1999). ilköğretim okulları 4. sınıf öğretmenlerinin sosyal bilgiler dersinde düşünme becerilerini kazandırma yeterliklerinin değerlendirilmesi. Unpublished Master's Thesis, Çukurova University, Adana.

Goodnight, G. T. (2006). Complex cases and legitimation inference: extending the Toulmin model to deliberative argument in controversy. (Eds. D. Hitchcock, B. Verheij). Arguing on the Toulmin Model. pp. 39-48. Netherlands: Springer.

Günel, M., Kıngır, S. \& Geban, Ö. (2012). Argümantasyon tabanIı bilim öğrenme(ATBÖ) yaklaşımının kullanıldığı sınıflarda argümantasyon ve soru yapılarının incelenmesi [Analysis of argumentation and questioning patterns in argument-based inquiry classrooms], Education and Science, 37(164), 317-328.

Gürkaynak, I., Üstel, F., \& Gülgöz, S. (2008). Eleştirel düşünme. Eğitim Reformu Girişimi. Retrieved from: http:// www.egitimreformugirisimi.org/wp-content/up- 
loads/2017/03/Elestireldusunme 0.pdf

Gültepe, N. (2011). Bilimsel tartışma odaklı öğretimin lise öğrencilerinin bilimsel süreç ve eleştirel düşünme becerilerinin geliştirilmesine etkisi. Unpublished Doctoral Dissertation, Gazi University, Ankara.

Güzel, S. (2005). Eleștirel düşünme becerilerini temele alan ilköğretim dördüncü sınıf sosyal bilgiler öğretiminin ögrenme ürünlerine etkisi. Unpublished Master's Thesis, Mustafa Kemal University, Hatay.

Hacıoğlu, Y. (2011). Bilimsel tartışma destekli örnek olayların 8. sınıf öğrencilerinin kavram öğrenmelerine ve okuduğunu anlama becerilerine etkisinin incelenmesi: Genetik. Unpublished Master's Thesis. Marmara University istanbul.

Hesapçığlu, M. (1991). Etkin okul araştırmaları. Kültür Koleji Genel Müdürlüğü (Ed.), Eğitimde nitelik geliştirme: Eğitimde arayışlar sempozyumu bildiri metinleri (s. 238- 243). İstanbul: Kültür Koleji Yayınları.

Hudson, R. A. (2010). Statistical argumentation in project-based learning environments. Unpublished Doctoral Dissertation, University of Indiana, Indiana.

ilter, i. (2013). Sosyal bilgiler dersinde sorgulayıcı- araştırma tabanlı öğrenme modeli: başarı ve öğrenmede kalıcılığın etkisi. Turkish Studies, 8(12), 591-605.

Kabapınar, Y. (2014). Kuramdan uygulamaya sosyal bilgiler ögretimi, Ankara: Pegem Akademi.

Kabataş- Memiş, E. (2014). İlköğretim öğrencilerinin argümantasyon tabanlı bilim öğrenme yaklaşımı uygulamalarına ilişkin görüşleri [Elementary students' ideas about on implementation of argumentation-based science learning approach], Kastamonu Education Journal, 22(2), 401-418.

Kardaş, N. (2013). Fen eğitiminde argümantasyon odaklı öğretimin ögrencilerin karar verme ve problem çözme becerilerine etkisi. Unpublished Master's Thesis, Eskişehir Osmangazi University, Eskişehir.

Kelly, G., \& Takao, A. (2002). Epistemic levels in argument an analysis of university oceanography students' use of evidence in writing. Science Education, 86, 314-342.

Kıngır, S. (2011). Using the science writing heuristic approach to promote student understanding in chemical changes and mixtures. Unpublished Doctoral Dissertation, Middle East Technical University, Ankara.

King, A. (1997). Ask to think-tell why: model of transactive peer tutoring for scaffolding higher level complex learning. Educational Psychologist, 32(4), 221-235.

Kolsto, S. D. (2006). Patterns in students' argumentation confronted with a risk-focused socio-scientific issue. International Journal of Science Education, 28(1), 16891716.

Kuhn, D., \& Moore, W. (2015). Argumentation as core curriculum. Learning: Research and Practice, 1(1), 66-78.

Kuhn, D., \& Udell, W. (2003). The development of argument skills. Child Development, 74(5), 1245-1260.

Küçük, H. \& Aycan, H. Ş. (2014). 2007-2012 yılları arasında bilimsel tartışma üzerine gerçekleştirilmiş açık erişim araştırmaların bir incelemesi [Examining open access studies on argumantation between the years 20072012]. MSKU Journal of Education,1(1), doi:10.21666/ mskuefd.05345
Larson, A. A., Britt, M. A., \& Kurby, C. A. (2009). Improving students' evaluation of informal arguments. The Journal of Experimental Education, 77(4), 339-365.

Merriam, S. B. (2013). Qualitative research and case study applications in education. San Francisco: Jossey-Bass Publishers.

Ministry of National Education [MNE]. (2017). Sosyal bilgiler dersi öğretim programı (1.-8. sınıflar) [Social studies curriculum (1st - 8th grade)]. Board of Education and Discipline, Ankara, Turkey.

Mirza, N. M., \& Perret-Clermont, A. N. (2009). Argumentation and education theoretical foundations and practices. (Eds. Clermont), London: Springer Press.

Nussbaum, E. M., (2002). Scaffolding argumentation in the social studies classroom. The Social Studies, 93(2), 7983.

Nussbaum, E. M. (2008). Using argumentation vee diagrams (avds) for promoting argument counterargument integration in reflective writing. Journal of Educational Psychology, 100(3), 549- 565.

Nutt, P. C. (2008). Investigating the success of decision-making processes, Journal of Management Studies, 45(2), 425-455.

Osborne, J., Erduran, S., \& Simon, S. (2004). Enhancing the quality of argumentation in school science. Journal of Research in Science Teaching, 41(10), 994-1020.

Önal, H. ve Kaya, N. (2011). Sosyal bilgiler ders kitaplarının (4. ve 5. sınıf) değerlendirilmesi [The evaluation of social studies textbooks of fourth and fifth grade], Sosyal Bilimler Dergisi, 3(1), 179-189.

Özkara, D. (2011). Basınç konusunun sekizinci sınıf öğrencilerine bilimsel argümantasyona dayalı etkinlikler ile ögretilmesi. Unpublished Master's Thesis, Adıyaman University, Adıyaman.

Patronis, T., Potari, D., \& Spiliotopoulou, V. (1999). Students' argumentation in decision making on a socio-scientific issue: Implications for teaching. International Journal of Science Education, 21(7), 745-754.

Sadler, T. D., \& Fowler, S. R. (2006). A threshold model of content knowledge transfer for socioscientific argumentation. Science Education, 90(6), 986-1004.

Sampson, V., \& Clark, D. (2007). Incorporating scientific argumentation into inquiry-based activities with online personally-seeded discussions. The Science Scope, 30(6), 43-47.

Simon, S., Erduran, S., \& Osborne, J. (2006). Learning to teach argumentation: research and development in the science classroom. International Journal of Science Education, 28, 235-260.

Simon, S., \& Richardson, K., (2009). Argumentation in school science: breaking the tradition of authoritative exposition through a pedagogy that promotes discussion and reasoning. Argumentation, 23, 469-493.

Swartz, R. J., (2008). Teaching students how to analyze and evaluate arguments in history. The Social Studies, 99(5), 208-216. 
Tekeli, A. (2009). Argümantasyon odaklı sınıf ortamının öğrencilerin asit-baz konusundaki kavramsal değişimlerine ve bilimin doğasını kavramalarına etkisi. Unpublished Master's Thesis, Gazi University, Ankara.

Toulmin, S. (1958). The uses of argument. Cambridge: Cambridge University Press.

Torun, F. \& Şahin, S. (2016). Determination of students' argument levels in argumentation-based social studies course. Education and Science, 41(186), 233-251.

Thielemier, B. T. (2013). Developing emerging argumentation: using disparate forms of evidence to create instructional inroads. Unpublished Master's Thesis, Colorado State University, Colorado.

Wissinger, D. R. (2012). Using argumentative discussions to enhance the written arguments of middle school students in social studies classrooms. Unpublished Doctoral Dissertation, University of Maryland, Maryland.

Yazıcıoğlu, A. (2017). Sosyal bilgiler dersinin Toulmin tartışma modeline dayalı ögretimi. Unpublished Doctoral Dissertation, Pamukkale University, Denizli.

Yeşildağ-Hasançebi, F., \& Günel, M. (2013). Argümantasyon tabanlı bilim öğrenme yaklaşımının dezavantajı öğrencilerin fen bilgisi başarılarına etkisi [Effects of argumentation-based inquiry approach on disadvantaged students' science achievement], Elementary Education Online, 12(4), 1056-1073.

Yeşiloğlu, S. N. (2007). Gazlar konusunun lise öğrencilerine bilimsel tartışma (argümantasyon) odaklı yöntem ile öğretimi. Unpublished Master's Thesis. Gazi University, Ankara.

Yıldırım, A. \& Şimşek, H. (2016). Sosyal bilimlerde nitel araştırma yöntemleri. Ankara: Seçkin Yayıncılık.

Zohar, A., \& Nemet, F. (2002). Fostering students' knowledge and argumentation skills through dilemmas in human genetics. Journal of Research in Science Teaching, 39(1), 35-62. 